\title{
Pasta based on Sweet Potato: Optimization of Fiber Content in Response Surface Methodolgy
}

\author{
Bazil Wilfred.C, Elizabeth Amudhini Stephen.S, Rebecca Jebaseeli Edna.K, Kulastic Jassy
}

\begin{abstract}
Sweet potato as a high fibre supplement that can be used in the production of pasta. The production of sweet potato pasta was optimized by Response Surface Methodology. The parameters used for optimizing the products are solid loss, texture, fibre content. Box - behnken design was used to develop models for the response. For the production of sweet potato based pasta $174.285 \mathrm{~g}$ of sweet potato, $48.4735 \mathrm{~g}$ of water, $28.8296 \mathrm{~g}$ of soy flour, $2.69575 \mathrm{~g}$ of Arabic gum and $0.877038 \mathrm{~g}$ of cmc (carboxyl methyl cellulose). The responses were mostly deviated by changes in quantity of soy flour and Arabic gum and to a small extent the deviation by sweet potato and water levels. The result of this study showed a minimum solid loss of $13.45 \%$ and maximum texture hardness of $6994 \mathrm{~g}$ and maximum fibre content of $8.52 \mathrm{~g}$

Keywords: Sweet potato, soy flour, Arabic gum, carboxyl methyl cellulose, Response Surface Methodology, solid loss, texture hardness, fibre content.
\end{abstract}

\section{INTRODUCTION}

The sweet potato [Ipomoea batatas(L.) Lam.] is a plant that is dicotyledonous. It belongs to the family Convolvulaceae. Sweet potato is an important crop for food security and is cultivated in more than 100 developing countries. This tuberous crop is mostly for human consumption. In the periods of drought it acts as major subsistence crops. Two sweet potato varieties namely Barkume and Adu have been recommended for cultivation in eastern part of Ethiopia by Harmaya University (Solomon et al. 2015).

Commonly sweet potato is grown in tropical and subtropical regions of the world. Central America is the first place where sweet potato is grown and is now widely grown in other parts of Africa (including Nigeria), Latin America, the Pacific Islands and Asia. The growing period of sweet potato is 3-4 months. It has a unique sweetness and nutritional content. It has a great source of minerals and fibre that play a major role in reducing blood and aid digestion. Boiling, roasting, frying and baking are the common methods used to cook pasta before consumption (Adepojuet al. 2015).

Revised Manuscript Received on April 11, 2020.

* Correspondence Author

Bazil Wilfred .C, Assistant Professor, Department of Mathematics, Karunya Institute of Technology and Sciences, Coimbatore, India.

S,Elizabeth Amudhini Stephen*, Associate Professor, Department of Mathematics, Karunya Institute of Technology and Sciences, Coimbatore, India. elizi.felix@gmail.com

Rebecca Jebaseeli Edna.K, Assistant Professor, Department of Mathematics, Karunya Institute of Technology and Sciences, Coimbatore, India.

Kulastic Jassy, Department of Food Processing, Karunya Institute of Technology and Sciences, Coimbatore

(C) The Authors. Published by Blue Eyes Intelligence Engineering and Sciences Publication (BEIESP). This is an open access article under the CC BY-NC-ND license (http://creativecommons.org/licenses/by-nc-nd/4.0/)
The soybean (Glycine max) is the seed from a leguminous soybean plant. It has high protein content and an ideal source of protein supplementation of starchy foods. (Maha et al. 2011). Soya food has been an important food ingredient in Chinese diet for the past 4000 years but has been widely consumed in western countries. The protein present in soy lowers cholesterol levels. Soybeans also contain biologically active or metabolic proteins such as enzymes, trypsin inhibitors, hem agglutinins, and cystine protease. The proteins from the stored soy cotyledon are important for human nutrition. The isoflavones are said to have potential anticancer effects. (Venkateswari et al 2016). It can be use as a replacement for wheat in noodles which is also a rich source lysine. Economically high priced meat protein is present in soybean and it is observed to be the good source of protein especially in vegetarian diet. The nutrient level in pregnant woman, nursing mother, school going and young children can be increased by high protein soya. (Pakhare et al. 2016).

Gum Arabic (GA) or acacia gum is a by-product from the Acacia Senegal and Acacia seya trees, belonging to Leguminosae family. Arabic gum appears to be light orange or pale white pieces and is water soluble. Arabic gum is highly harvested in Sudan, Chad, Nigeria, Senegal, and Ethiopia. Arabic gum has been in use for about 5000 years. It is used in the treatment of chronic kidney diseases in the Middle Eastern countries. In food industry it is used in wide range of products like ice creams, jellies, candies, soft drinks, beverages, syrups and chewing gums. (Seema et al. 2015). Sodium Carboxymethyl Cellulose (CMC) is the most widely used and the largest amount of cellulose type in the world. It is carboxymethyl derivatives of cellulose, also known as cellulose gum, are the most important Ionic cellulose gum. Due to its thickening and emulsifying nature, it can stable acid milk beverage. It can increase the stickiness of yogurt system due to its hydrophilic and rehydration. It can also be used to improve the quality of pasta, bread and other food products. It extends the shelf life of bread and other pasta food and also improves their texture. Its gel effect can be used to make jellies and jams. It can also be used as an edible coating material, compounded with other thickeners. When smeared on the surface of some foods it may be used to keep food fresh. As it is edible, it does not have any adverse impact on human health. (Lucy Wong et al.2017). RSM (Response Surface Methodology) has been used as a tool for optimizing the process. It is used for different processes and defines the optimization of snack food based on amaranth (Jauregui et al. 2000). It is also used in the analysis of the effect of corn flour, green gram flour, xanthan, guar gum, Arabic gum and carboxy methyl cellulose (CMC) on the sensory and objective (expansion ratio)

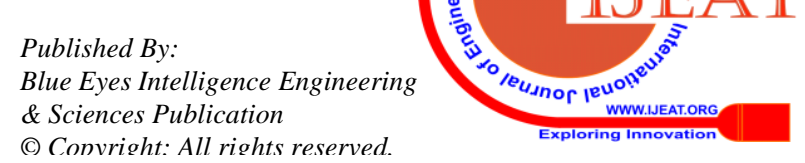


attributes of an extruded snack food and found that the responses were affected mostly by changes in corn flour, green gram flour and guar gum levels and to a lesser extent by xanthan, Arabic gum and CMC levels. (Thakur et al.2000).

\section{MATERIALS AND METHODS:}

\section{Materials:}

Sweet potato (cleaned, peeled, sliced, dried, ground and kept at $4^{\circ} \mathrm{C}$ ), defatted soy flour, Arabic gum, CMC (Carboxyl methyl cellulose).

METHODS:

\section{Pasta preparation:}

Pasta is produced by mixing all the raw ingredients together with water (moisture content of about $30 \%$ ). The mixture is continuously kneaded for 15 minutes so as to form stiff, homogenous dough and then can be made into any shape using tools.

\section{Solid loss:}

Solid loss after cooking can be calculated from the drained water. About $5 \mathrm{~g}$ of pasta is added to $200 \mathrm{ml}$ boiling water. After cooking, the water is drained. From the drained water about $10 \mathrm{~g}$ is weighed in a beaker. The beaker is then kept in the boiling water bath for 5 minutes. The water in beaker evaporates and the solid loss is calculated,

Solids loss $(\%)=$ AB $^{*}$ 100/CD.

A defines weight of the residue,

B defines volume of cooking water $(250 \mathrm{ml})$,

C defines initial sample weight (10 g),

$\mathrm{D}$ defines volume of sample taken for residue estimation $(10 \mathrm{ml})$.

\section{Texture:}

Texture of uncooked pasta is measured using a texture analyser.

\section{Fibre content:}

Fibre content of the product can be found from the ash of the sample. The sample is taken in a crucible and kept in the cool muffle furnace for about $10-14 \mathrm{hrs}$ at $550^{\circ} \mathrm{C}$. Once the crucible is removed from the furnace the weight of the sample is taken, and the weight of ash is noted as the fibre content.

\section{Response estimation:}

The pasta samples are tested several times to estimate the minimum solid loss after cooking, maximum texture and maximum fibre content.

\section{Experimental design:}

The study was conducted according to Box - Behnken method with three dependent variables $(\mathrm{Y})$, solid loss $\left(\mathrm{Y}_{1}\right)$, texture $\left(\mathrm{Y}_{2}\right)$ and fibre content $\left(\mathrm{Y}_{3}\right)$. The five independent variables are sweet potato flour (A), water (B), Soy flour (C), Arabic gum (D), CMC (E). A total of 40 combinations were tested to interpret the response.

Table: 1 , shows the variables and responses used in the options

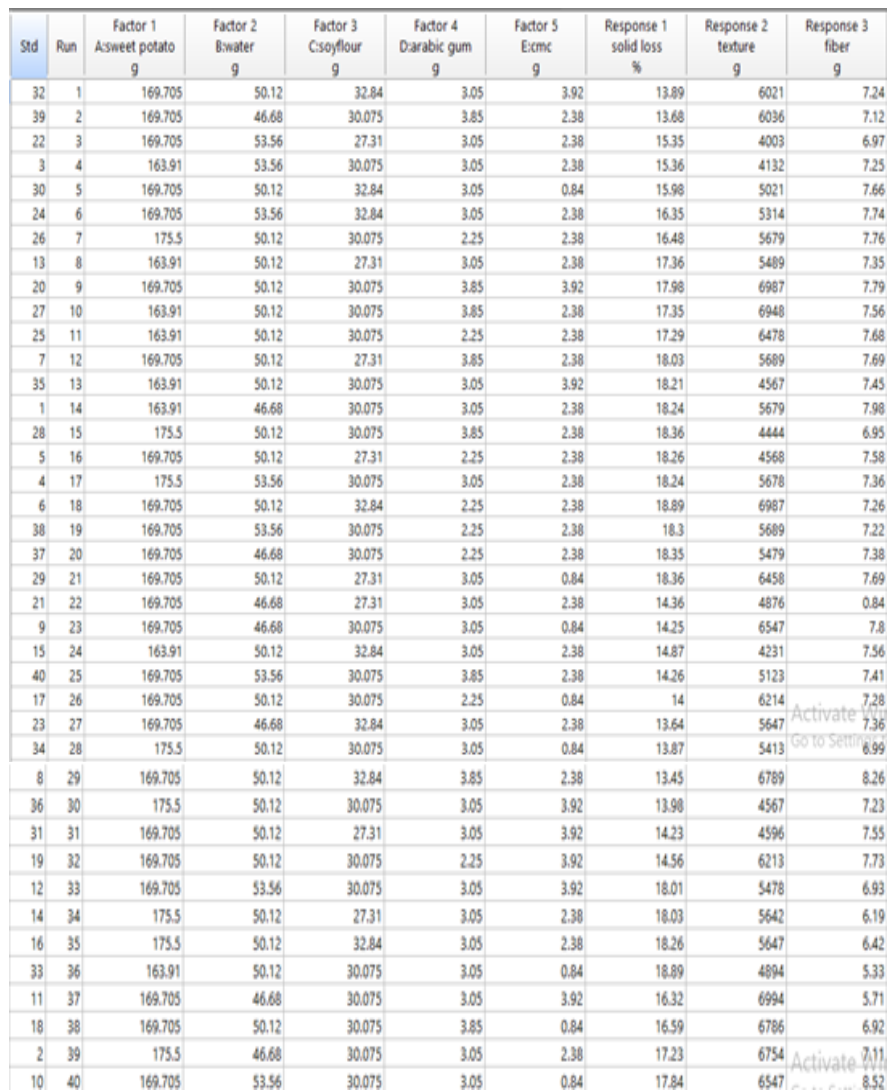

Table 1: Box- Benhken method with values of response variables for pasta production using sweet potato.

\section{RESULTS AND DISCUSSIONS:}

\section{Solid Loss:}

Water and sweet potato flour have a great effect on the solid loss. Solid loss is maximum when the amount of sweet potato is at its maximum. The solid loss increases with increase in water as defined in the below given fig (1a, 2a, 3a, 4a, 5a, 6a). The response equation of solid loss is given below,

$$
\mathrm{Y}_{1}=22.84089-0.033650 \mathrm{~A}+0.138808 \mathrm{~B}-
$$

$0.195524 \mathrm{C}-0.502344 \mathrm{D}-0.105519 \mathrm{E}$.

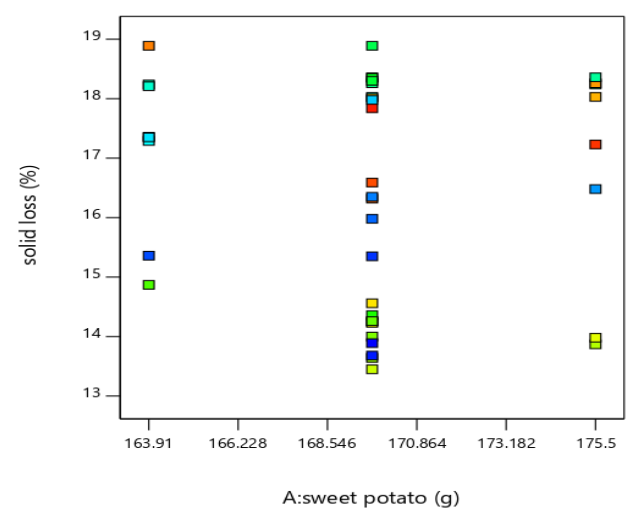

Published By:

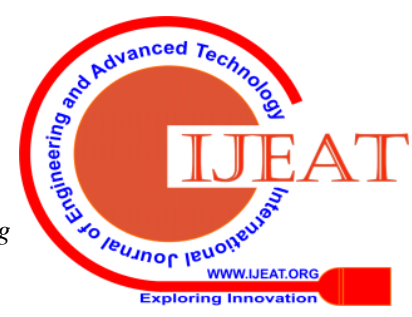




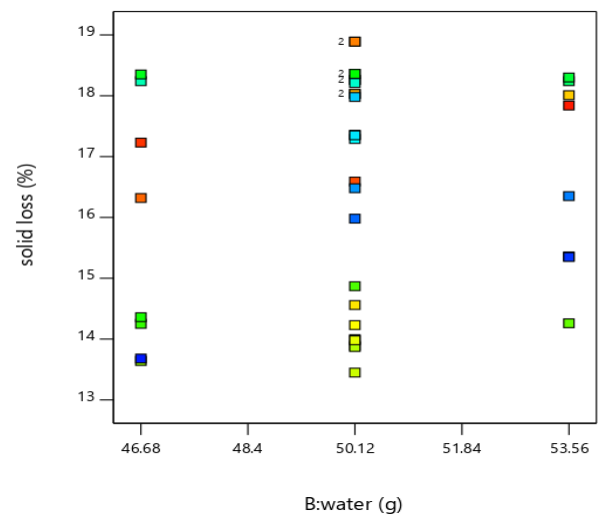

Fig (1): Solid loss vs Sweet potato Fig(2) Solid loss vs Water
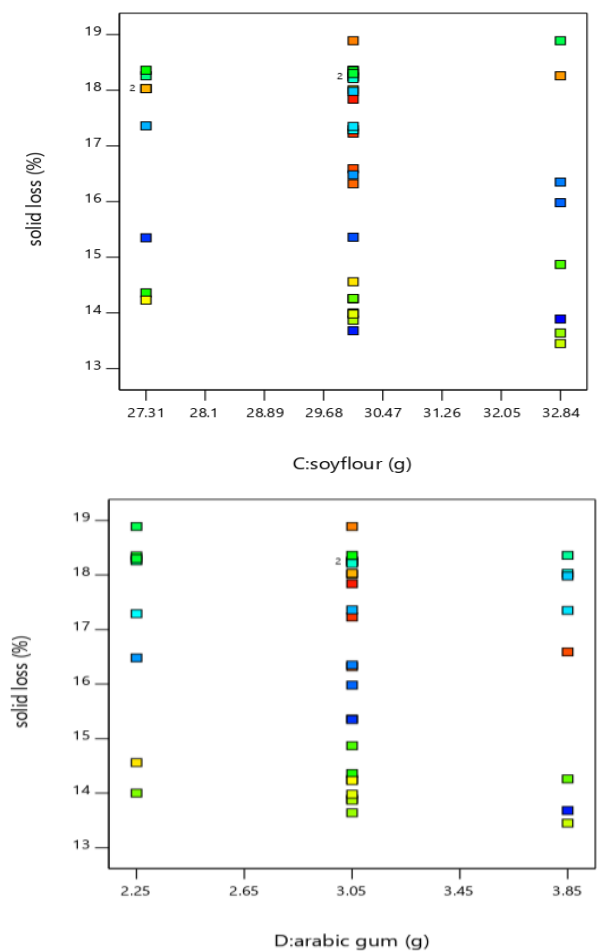

Fig (3): Solid loss vs. Soy flour Fig (4): Solid loss vs. Arabic gum
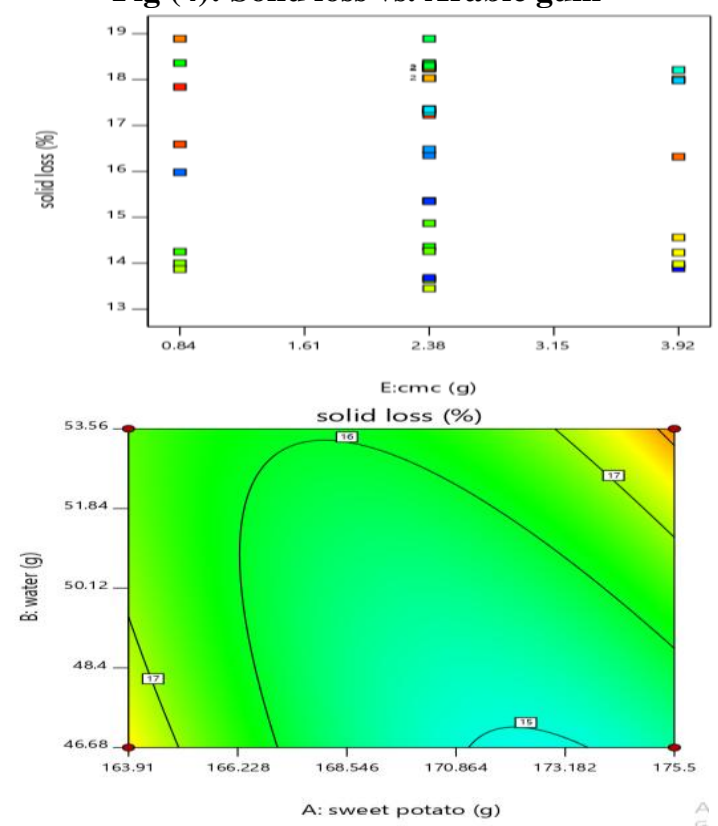

Fig (5) Solid loss vs. CMC

Fig (6) Solid loss vs. Variables

Retrieval Number: C5316029320/2020@BEIESP

\section{TEXTURE:}

The texture of pasta is more significantly required for its quality. The effect of texture is influenced by both water and sweet potato. The texture highly depends on sweet potato compared to the water. The texture increases with an increased amount of sweet potato as it has high amount of starch, the fig (1b, 2b, 3b, 4b, 5b, 6b) defines it. The response equation of texture is given as follows,

$$
\mathrm{Y}_{2}=5524.99369+15.16393 \mathrm{~A}-10988372 \mathrm{~B}+
$$

$98.01085 \mathrm{C}+116.79687 \mathrm{D}-99.71591 \mathrm{E}$
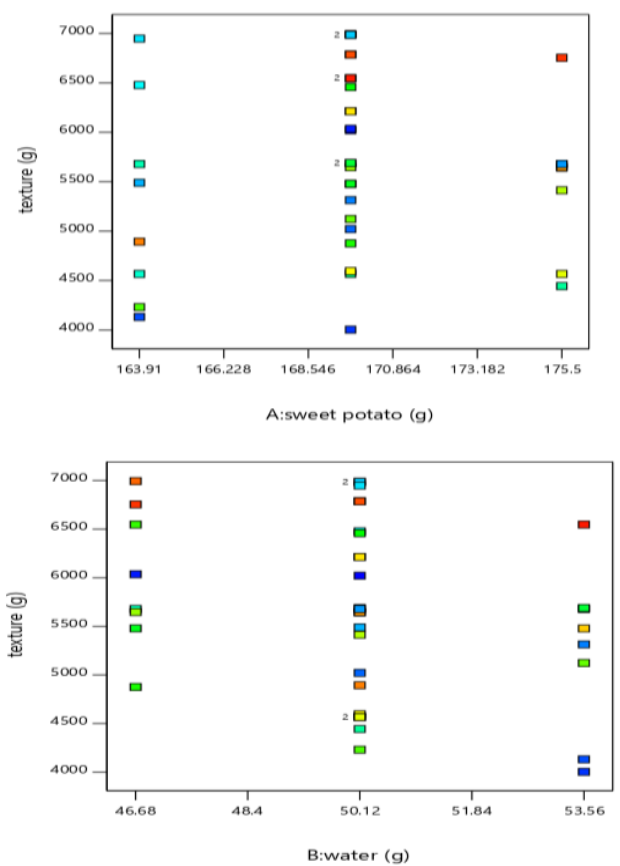

Fig (1b): Texture vs Sweet po Fig(2b): Texture vs Water.

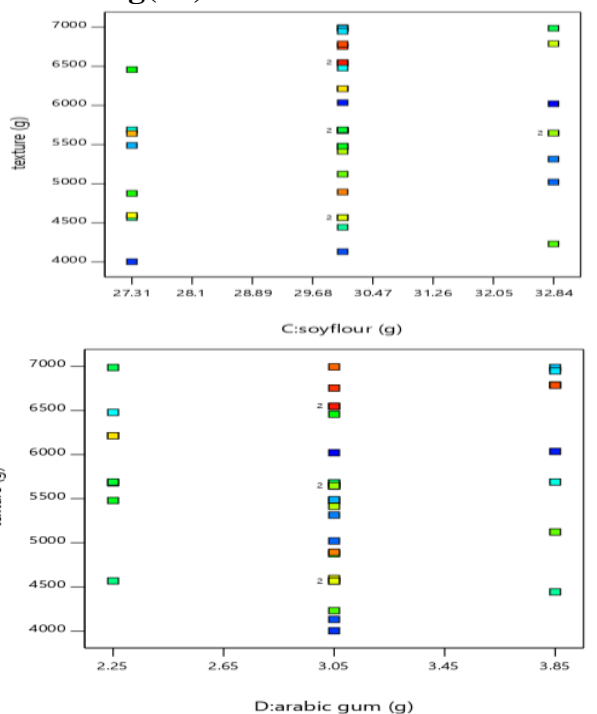

Fig (3b): Texture vs. Soy flour Fig (4b): Texture vs. Arabic gum

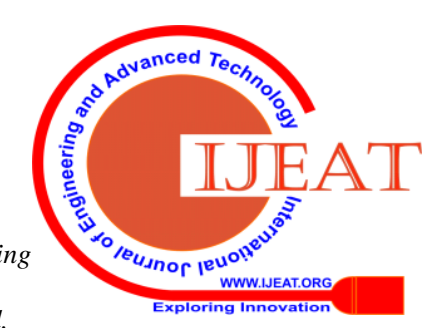



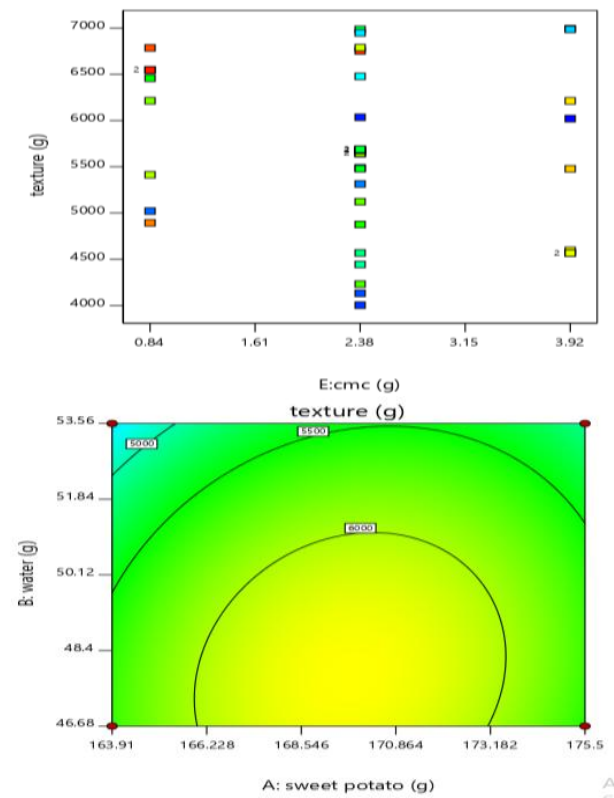

Fig (5b): Texture vs. CMC.

Fig (6b): Texture vs. Water and sweet potato

\section{FIBRE CONTENT:}

Fibre content of the product is important as it is made of sweet potato. The fibre content of the pasta defines the nutritional value of the product. Fibre content increases with an increased amount of sweet potato as shown in fig (1c, 2c, 3c, 4c, 5c, 6c). The response equation of fibre content is defined as, $\mathrm{Y}_{3}=11.08148-0.008952 \mathrm{~A}-0.038336 \mathrm{~B}+0.006555 \mathrm{C}-$ $0.296875 \mathrm{D}-0.004464 \mathrm{E}$
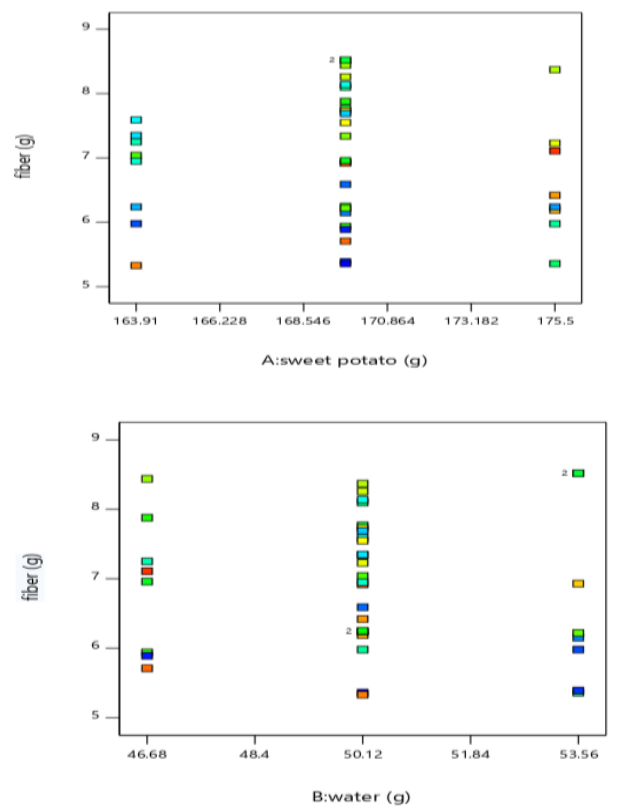

Fig (1c): Fibre vs. Sweet potato Fig (2c): Fibre vs. Water
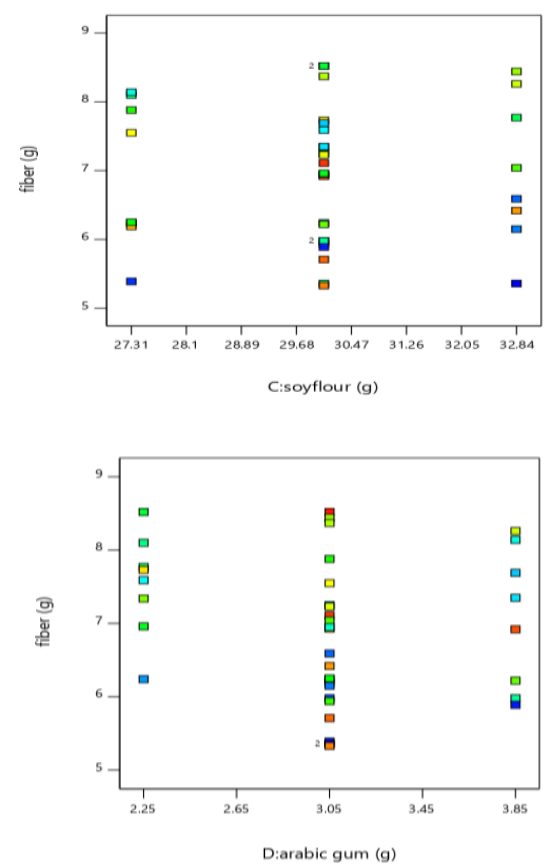

Fig (3c): Fiber vs. Soy flour.

Fig (4c): Fiber vs. Arabic gum.
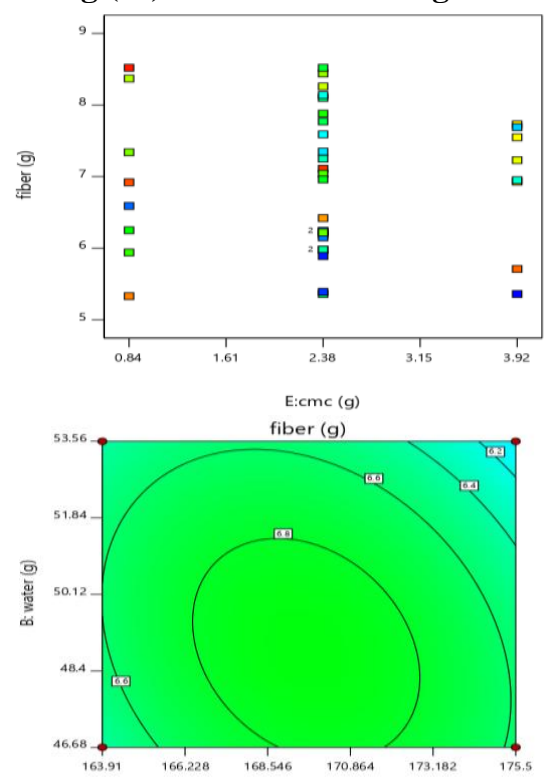

A: sweet potato (g)

Fig (5c): Fibre vs. CMC.

Fig (6c): Fibre vs. sweet potato and water.

\section{CONCLUSION:}

Pasta is a sweet potato based product with high fibre as its nutrient source. The study of the product shows a minimum solid loss of $13.45 \%$ and maximum texture hardness of $6994 \mathrm{~g}$ and maximum fibre content of $8.52 \mathrm{~g}$ for $163.91 \mathrm{~g}$ to $175.5 \mathrm{~g}$ of sweet potato, $46.68 \mathrm{~g}$ to53.56g of water, $27.31 \mathrm{~g}$ to $32.84 \mathrm{~g}$ of soy flour, $2.25 \mathrm{~g}$ to $3.85 \mathrm{~g}$ of Arabic gum, $0.84 \mathrm{~g}$ to $3.92 \mathrm{~g}$ of CMC. whereas in another study of the same product defines maximum sensory score (33.8), minimum solids loss (16.6\%) and maximum texture hardness (5616 g) were identified at $674 \mathrm{~g} \mathrm{~kg}^{-1}$ sweet potato flour, $195 \mathrm{~g} \mathrm{~kg}^{-1}$ of water, $110 \mathrm{~g} \mathrm{~kg}^{-1}$ of soy flour, $10.6 \mathrm{~g} \mathrm{~kg}^{-1}$ of Arabic gum and $10.1 \mathrm{~g} \mathrm{~kg}^{-1}$ of CMC levels.(Sukhcharn Singh et al. 2004).

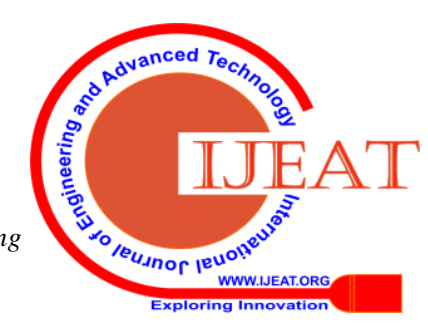




\section{REFERENCE:}

1. Adepoju, A. L. (2015). Some Proximate Properties Of Sweet Potato (Ipomoea Batatas L) As Influenced By Cooking Methods. INTERNATIONAL JOURNAL OF SCIENTIFIC \& TECHNOLOGY RESEARCH , 26-26.

2. Goyal, S. P. (2015). Applications of Natural Polymer Gum Arabic: A review. International Journal of Food Properties , 986-998.

3. Jauregui, R.N.C., Silva, M.E.M.P. \& Areas, J.A.G. (2000). Extrusion cooking process for amaranth (Amaranthus caudatus L.). Journal of Food Science, 65, 1009-1015.

4. Maha A. M. Ali, A. H. (2012). Effect of Different Supplementation Levels of Soybean Flour on Pearl Millet Functional Properties. Food and Nutrition Sciences, , 1-6.

5. Pakhare KN, D. A. (2016). Studies on Preparation and Quality of Nutritious Noodles by Incorporation of defatted rice bran and soy flour. Journal of Food processing and technology , 7-11.

6. Parameshwari, P. V. (2016). Effect of incorporation of soya flour to wheat flour on nutritional and sensory quality of biscuits. International Journal of Applied Research , 827-832.

7. Solomon Ali, W. M. (2015). Agronomic and Physicochemical Evaluation of Sweet Potato [Ipomoea. Advances in Crop Science and Technology , 50-62.

8. Sukhcharn Singh, C. S. (2004). Sweet potato-based pasta product: optimization of ingredient levels using response surface methodology. International Journal of Food Science and Technology , 191-200.

9. Thakur, S. \&Saxena D.C. (2000). Formulation of extruded snack food (gum based cereal-pulse blend): optimization of ingredients levels using response surface methodology. Lebensmittel Wissensc haft and technologies, 33,354-361.

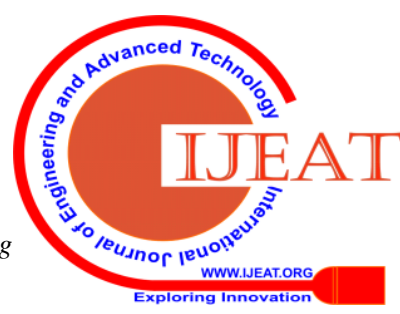

